\section{Changes in sexual behavior following a sex education program in Brazilian public schools}

\author{
Mudanças no comportamento sexual de \\ adolescentes de escolas públicas no Brasil \\ após um programa de educação sexual
}

\author{
1 Associação Beneficente dos \\ Empregados das Empresas \\ Arcelor Brasil, \\ Belo Horizonte, Brasil. \\ 2 Fundação Belgo/Grupo \\ Arcelor Brasil, Belo \\ Horizonte, Brasil. \\ 3 Instituto de Comunicação \\ e Informação Científica \\ e Tecnológica em Saúde, \\ Fundação Oswaldo Cruz, \\ Rio de Janeiro, Brasil. \\ ${ }_{4}$ Centro de Pesquisas em \\ Saúde Reprodutiva de \\ Campinas, Campinas, Brasil. \\ 5 Faculdade de Ciências \\ Médicas, Universidade \\ Estadual de Campinas, \\ Campinas, Brasil. \\ Correspondence \\ H. H. S. M. Andrade \\ Associação Beneficente dos \\ Empregados das Empresas \\ Arcelor Brasil. \\ Av. Bernardo Monteiro 831, \\ Belo Horizonte, $M G$ \\ 30150-281, Brasil. \\ heloisa.andrade@arcelor.com.br
}

\begin{abstract}
This paper describes an evaluation of possible changes in sexual behavior in adolescents who participated in a school-based sex education program in selected public schools in four municipalities in the state of Minas Gerais, Brazil. The program is inserted within the context of reproductive rights, deals with risks involved in unsafe sexual practices and focuses on the positive aspects of sexuality. A quasi-experimental design with pre and post-tests and a non-equivalent control group was used to evaluate the intervention. A total of 4,795 questionnaires were included in this analysis. The program succeeded in more than doubling consistent condom use with casual partners and in increasing the use of modern contraceptives during last intercourse by $68 \%$. The intervention had no effect on age at first intercourse or on adolescents' engagement in sexual activities. The sex education program was effective in generating positive changes in the sexual behavior of adolescents, while not stimulating participation in sexual activities.
\end{abstract}

Sexual Behavior; Sex Education; Adolescents
Heloísa Helena Siqueira Monteiro Andrade 1,2 Maeve Brito de Mello ${ }^{3}$

Maria Helena Sousa 4

Maria Yolanda Makuch 4

Neilane Bertoni 3

Anibal Faúndes 4,5

\section{Introduction}

Over the past twenty years, increased attention has been paid to adolescent reproductive health issues and to the awareness that adolescence is the appropriate time at which to introduce interventions to improve their present and future health and social welfare in many developed and developing countries 1 . International organizations and many governments consider sexual and reproductive health and the prevention of drug use and violence as important elements in a comprehensive approach to adolescent health 2 . Formal sexual health education for adolescents has been influenced by changing government policies and by public opinion. Consequently, it is imbued with different ideologies and is organized according to a diversity of strategies. The degree of success of these programs in promoting behavioral changes varies from one to another, but overall they result in the adoption of safer sexual practices by youth ${ }^{3}$.

In Brazil, sex education programs that target adolescents started to be implemented at the beginning of the last century. In the late 1980s, apart from a few religion-related programs, the majority of Brazilian sex education initiatives dealt with sexuality as a positive and healthy experience, in many cases as a partnership between nongovernmental organizations and the public sector. Within the latter approach, some educators began to deal with sex education in a political 
context as a way of promoting social changes 4,5 . Rare were the programs in Brazil that focused on abstinence only as a strategy for the prevention of STD/HIV/AIDS or early pregnancy.

Following the AIDS pandemic, many schoolbased programs started to give greater emphasis to the promotion of safer sexual practices. Only in 1998, however, was sex education officially included in the Brazilian national school curriculum 6 , and more recently, in 2003, a program was launched by the National STD and AIDS Programme in partnership with the Ministry of Education to make condoms available in public schools, although its implementation in schools was rather limited 7 . Findings from the 2005 school census showed that $60 \%$ of Brazilian schools had STD/AIDS prevention programs, many of which as a result of municipal government initiatives, however only $9 \%$ offered condoms to students 7 . Moreover, as in many developing countries, most of these programs did not include systematic monitoring or evaluation of their effectiveness, especially with respect to behavioral change 3,8 .

From 1994 through 1998 a sex education project was implemented in 60 public schools in the city of Belo Horizonte, Minas Gerais State, by two local NGOs, Humbiumbi and Prosex, sponsored by the Odebrecht Foundation 9. An evaluation of the project highlighted the need for integration with health services and for the inclusion of health indicators in the project, resulting in changes to the project's theoretical framework, objectives and teacher training agenda 10 . In 1999, the State Departments of Education and Health of the State of Minas Gerais, in partnership with the Odebrecht Foundation, incorporated those changes and transformed this project into a state-wide program. This new sex education program, named Programa de Educação Afetivo-Sexual (PEAS): Um Novo Olhar [the Programme for Sexual and Emotional Education: A New Perspective] also incorporated evaluation as a fundamental component of its strategy. The program was implemented in approximately 45 municipalities in the State of Minas Gerais.

In the year 2000, the program was also implemented in another five municipalities by another private non-profit organization, the Belgo Foundation. This initiative was referred to as PEAS Belgo, and also incorporated a direct partnership with the municipalities, the training of at least $60 \%$ of staff in participating schools and a system to monitor most of the actions of the program into the program strategy.

The objective of this study was to evaluate possible changes in the sexual behavior of adolescents who participated in the PEAS Belgo sex education program in public schools in four of the five municipalities.

\section{Subjects and methods}

\section{Intervention}

The PEAS Belgo program was based on the principle that sex education is a right, and an essential component of the personal and social development of adolescents. The program was inserted within the context of sexual and reproductive rights, and dealt not only with the risks involved in unsafe sexual practices but also focused on the positive aspects of sexuality. It emphasized the importance of intra and interpersonal relationships in the context of a healthy and pleasurable sex life, and stimulated gender equity with the aim of reducing the vulnerability of adolescents.

The program focused on the development of a stronger feeling of citizenship and favored "youth protagonism", defined as the creation of opportunities for adolescents to participate in school activities as a means of stimulating the development of their decision-making capacity with autonomy and responsibility 11 . Adolescents were actively stimulated to take part in the teaching-learning process, and to develop positive adult-adolescent relationships.

Objective, clear and updated information was provided on sexuality and reproductive health in the understanding that the acquisition of relevant knowledge and skills could lead to changes in attitude and behavior. The purpose was to contribute to reducing unplanned pregnancies and preventing STI through the adoption of more responsible sexual behavior, including an increase in condom and contraceptive use.

Program activities were developed both inside and outside the classroom throughout the entire school year, and promoted the selection of themes for discussion that were related to the program objectives, as well as the development of research projects. These projects were planned, implemented and evaluated in a participatory process. The program integrated both education and health professionals, students' families and the local community within the school environment.

The systematic training of education and health professionals was one of the main instruments used to achieve the program objectives. Over 350 professionals from the five municipalities involved participated in an 80-hour training program between August 2000 and April 2003, administered by the team from the Beneficent 
Association of Employees of the Belgo-Mineira Metallurgy Company (ABEB). This team has been administering the Integrated Program of Adolescent Healthcare (PAIA) since its implementation in 1992 12. Following training, teachers helped the adolescents to elaborate several projects related to the themes of sexuality and reproductive health through educative, participatory and preventive actions, with the objective of stimulating the adolescents to develop their self-esteem, take care of themselves and reflect on their own life projects. The adolescents developed several activities dealing with sexuality-related issues such as the elaboration of radio programs, school newspapers, theatrical plays, workshops and research projects. Following presentation of the projects, each school received a kit containing specific information, as well as educational materials and communication tools from the Belgo Foundation.

The present evaluation is on program intervention and involved around 9,000 adolescents in 20 public schools in four municipalities in the State of Minas Gerais (Contagem, João Monlevade, Juiz de Fora and Vespasiano). Schools participating in the program were chosen by program managers based on several criteria aimed at facilitating the success, sustainability and capacity for dissemination of the program. These criteria included previous participation in a quality education program and being capable of playing a leading role in disseminating program activities to other schools in the vicinity.

\section{Evaluation}

The evaluation framework was based on the principal theoretical premises of the program, which assumed that with the acquisition of relevant knowledge, a more positive attitude towards sexuality and gender issues, as well as more "protagonist" behavior would lead to the adoption of safer sexual practices by participants. The design used to evaluate the program was quasi-experimental with pre-test/post-test and non-equivalent control groups.

\section{Data collection}

A baseline survey was conducted with adolescents in the four municipalities of the State of Minas Gerais in 2000 and the post-test was carried out in the same schools approximately 18 months later, in 2002. All schools in these municipalities involved in the program that taught grades 6 through 8 were included in the evaluation. Comparison schools were chosen by each municipality program manager based on similar socioeconomic background of the students and geographical proximity to the program schools.

For the baseline survey, the classes included were selected from among the final three grades of Brazilian elementary schools (grades 6 to 8). From this universe, 23 classes were selected for the program and another 23 to compose the comparison group, using a systematic sampling method. In the post-test, the same sampling method was used to select classes from the same grades. In program schools, however, only classes in which at least half the students declared (in an enquiry conducted by local program managers) that they had participated in program activities were eligible to be included in the sample. These represented $87.5 \%$ of all grade 6 to 8 classes in program schools. All students from the selected classes were invited to participate in the evaluation. Only those aged 10 to 19 were included in the data analysis. The survey was performed by the research team from the Centro de Pesquisas em Saúde Reprodutiva de Campinas (CEMICAMP) with the local collaboration of representatives of all the partners involved in program implementation.

The instrument used for data collection was a self-administered, multiple-choice questionnaire containing questions designed to give an answer to each specific program objective. The questionnaire was pre-tested with similar groups of students in other municipalities.

The reliability of the three score-type questions (practice of protagonism, attitudes towards gender and sexuality issues) included in the instrument were assessed using Cronbach's alpha 13 , none having an alpha below 0.75 . In this paper, only questions related to sexual behavior are presented. Sexual behavior was investigated according to the following aspects: ever having engaged in sexual practices (defined as oral sex, penile-vaginal and penile-anal contact or penetration), age at first intercourse, use of condoms at every act of intercourse with a steady or casual partner, and use of any modern contraceptive method (defined as hormonal or barrier contraception) during last sexual intercourse.

\section{Sample size}

The sample size was calculated for the four municipalities based on the estimated proportion of $51.4 \%$ condom use at last sexual intercourse with a steady partner by adolescents aged 10 to 19 14. Type I error (alpha) was set at 0.05 , type II (beta) at 0.20 , and the expected absolute difference between groups at $6 \%$ resulting in 1,115 students per group 15. Considering the four groups (comparison and program at baseline and in the 
post-test), sample size was established at 4,460 students.

Based on the authors' previous experience, only $40 \%$ of students in each class were expected to participate in the study, mainly due to the fact that adolescents frequently forget to bring their parents' written authorization on the day set for application of the questionnaire. No information was collected from those who did not participate in the evaluation.

\section{$\underline{\text { Data analysis }}$}

Data analyses were performed by logistic regression models using a multilevel approach 16, which is able to control for the clustering-effect of students belonging to the same schools and for potential variability between individuals, schools and municipalities. Dependent variables related to sexual practices that were analyzed were: ever having engaged in sexual practices, use of condoms at every act of sexual intercourse with a steady partner, use of condoms at every act of sexual intercourse with a casual partner, and use of any modern contraceptive method at last sexual intercourse. Cox multilevel regression model was used to analyze age at first intercourse.

Independent variables at the individual level included dummy variables at all levels for sex; age (10 to 14 vs. 15 to 19); school grade attended (6 ${ }^{\text {th }}$ or $7^{\text {th }}$ vs. $8^{\text {th }}$ ); whether classes attended were during the day or in the evening; ethnicity (white vs. non-white); Catholic religion; evangelical religion; importance given to religion (great importance vs. others); and mother's educational level (up to elementary school vs. higher education levels). With respect to the school, the variable "number of students enrolled" was also included (the median was used as a cutoff point). With respect to the municipality, variables were: the semester in which the surveys were performed and the municipalities in which the schools were located (three municipalities were included in the models as dummy variables in relation to the fourth, Contagem, which was selected at random).

Three intermediate variables, which were part of the conceptual framework, were also included in the models as independent variables: practice of protagonism and attitudes towards gender and sexuality issues (the median scores were used as cut-off points). The main independent variables, which indicate program results were "group" (program vs. comparison group), "time" (baseline vs. post-test), and the "interaction" between "group" and "time". Results of this interaction term indicated the net effect of the program. The association between dependent variables and the three main independent variables used as indicators of program success are presented as fitted odds ratios (OR) and their respective 95\% confidence intervals (95\%CI) 17 .

Two independent variables, one of which was included in the conceptual framework and in the models, included a high percentage of missing values ( $18 \%$ for the practice of protagonism, and $16 \%$ for mother's education level). In order to maintain those individuals in the analysis, an imputation method was used replacing the missing values of these two variables by 0 , and adding two dummies in the models to indicate these replacements.

All models were run with and without the three intermediate variables to check for any possible endogenous effect on the interaction between the variables "group" and "time". Although there were differences in the coefficient of the interaction in all models, the inclusion of these intermediate variables did not change the significance level of the interaction "group" and "time". The software program used for data analysis was Stata, version 7.0 for Windows (Stata Corp., College Station, USA).

\section{Ethical considerations}

All students invited to participate in this study received an informed consent form ensuring them that all ethical aspects of social science research would be respected in accordance with the 196/96 Resolution of the Brazilian Health Council of the Ministry of Health. All students participating in the study were required to sign this form and those who were 17 years of age or younger also had to provide the signed consent of their legal guardian in order to participate. The research protocol and the consent form were approved both by the Internal Review Board of the institution and the Research Ethics Committee of the School of Medical Sciences of the State University of Campinas.

\section{Results}

\section{Sample characteristics}

A total of 4,795 questionnaires were filled out by students in the four municipalities included in this analysis, representing a response rate of approximately $38 \%$.

The sample was composed of students aged 10 to 19 years, most of whom were female, Catholic, gave great importance to religion and considered themselves as belonging to a non-white ethnic group. Approximately two-thirds of the 
adolescents' mothers had attended school up to elementary level (Table 1).

\section{Prevalence of sexual activity and} safe sexual practices

The median age at first sexual intercourse calculated by life table analysis was approximately 16 years in both groups and in the two periods, with male adolescents initiating sexual activity at around 15 years of age and females between 17 and 18 (data not shown in table).

The percentage of students in both groups, before and after the intervention, who declared that they had at some time engaged in sexual activities, was around $30 \%$, with a small, non-significant variation according to time and group. Condom use in all sexual encounters varied from close to $59 \%$ to just over $70 \%$, with little difference between use with casual or steady partners. Use of modern contraceptive methods at last sexual intercourse among those sexually active ranged from just below $70 \%$ to just below $80 \%$ (Table 2). The proportion of students using condoms and modern contraception was 10 or more percentage points higher following the intervention in the schools participating in the program, while there was virtually no difference over time in the comparison schools.

Although some differences in the prevalence of sexual practices between groups and periods were observed, they cannot be interpreted without controlling for a number of confounders such as age and gender distribution, which varied between groups and periods. These controlled results, calculated using multiple regression analysis, are shown in the next page.

Table 1

Percentage distribution of the main sociodemographic characteristics of students at program and comparison schools before and after program implementation.

\begin{tabular}{|c|c|c|c|c|}
\hline \multirow[t]{2}{*}{ Characteristics } & \multicolumn{2}{|c|}{ Before (\%) } & \multicolumn{2}{|c|}{ After (\%) } \\
\hline & Program & Comparison & Program & Comparison \\
\hline \multicolumn{5}{|l|}{ Sex } \\
\hline Male & 41.2 & 41.9 & 37.3 & 40.8 \\
\hline Female & 58.8 & 58.1 & 62.7 & 59.2 \\
\hline$n$ & 1,294 & 1,443 & 998 & 1,053 \\
\hline \multicolumn{5}{|l|}{ Age (years) } \\
\hline 10 to 14 & 73.9 & 70.9 & 77.5 & 76.4 \\
\hline 15 to 19 & 26.1 & 29.1 & 22.5 & 23.6 \\
\hline $\mathrm{n}$ & 1,295 & 1,446 & 999 & 1,055 \\
\hline \multicolumn{5}{|l|}{ Mother's schooling } \\
\hline Up to elementary level & 68.8 & 66.9 & 67.3 & 58.8 \\
\hline High school or above & 31.2 & 33.1 & 32.7 & 41.2 \\
\hline$n$ & 1,071 & 1,214 & 852 & 882 \\
\hline \multicolumn{5}{|l|}{ Ethnicity } \\
\hline White & 26.8 & 27.8 & 30.3 & 29.6 \\
\hline Non-white & 73.2 & 72.2 & 69.7 & 70.4 \\
\hline $\mathrm{n}$ & 1,286 & 1,436 & 997 & 1,050 \\
\hline \multicolumn{5}{|l|}{ Religion } \\
\hline Catholic & 72.1 & 70.5 & 68.6 & 70.3 \\
\hline Evangelical & 18.1 & 21.1 & 23.5 & 20.7 \\
\hline Other religion & 4.1 & 3.3 & 4.9 & 5.0 \\
\hline No religion & 5.7 & 5.2 & 2.9 & 4.0 \\
\hline $\mathrm{n}$ & 1,285 & 1,434 & 995 & 1,050 \\
\hline \multicolumn{5}{|l|}{ Importance given to religion } \\
\hline Very important & 68.9 & 72.3 & 70.0 & 68.2 \\
\hline Important & 25.1 & 22.2 & 25.3 & 26.1 \\
\hline Of little or no importance & 6.0 & 5.6 & 4.7 & 5.7 \\
\hline $\mathrm{n}$ & 1,289 & 1,435 & 995 & 1,051 \\
\hline
\end{tabular}


Percentage of students who declared themselves to be sexually active before and after program implementation, at program and comparison schools.

\begin{tabular}{|c|c|c|c|c|c|c|c|c|}
\hline \multirow[t]{3}{*}{ Sexual behavior } & \multicolumn{4}{|c|}{ Program schools } & \multicolumn{4}{|c|}{ Comparison schools } \\
\hline & \multicolumn{2}{|c|}{ Before } & \multicolumn{2}{|c|}{ After } & \multicolumn{2}{|c|}{ Before } & \multicolumn{2}{|c|}{ After } \\
\hline & $\mathbf{n}$ & $\%$ & $\mathbf{n}$ & $\%$ & n & $\%$ & $\mathbf{n}$ & $\%$ \\
\hline Ever having engaged in sexual practices & 1,219 & 29.8 & 952 & 26.6 & 1,352 & 33.6 & 992 & 30.2 \\
\hline Consistent condom use with casual partner & 218 & 58.3 & 156 & 71.8 & 273 & 65.9 & 187 & 63.6 \\
\hline Consistent condom use with steady partner & 187 & 58.8 & 137 & 70.1 & 228 & 63.6 & 151 & 62.3 \\
\hline Use of modern contraceptive at last intercourse & 260 & 68.1 & 191 & 78.5 & 334 & 73.1 & 230 & 72.6 \\
\hline
\end{tabular}

\section{Evaluation of changes in sexual practices after the intervention}

There were no differences in age at sexual debut according to the group, time or the interaction between group and time (hazard ratios of $1.03,0.95$ and 1.00 , respectively). There was also no difference in the proportion of students who had ever engaged in sexual practices (Table 3). The multiple logistic regression analysis also showed that the OR for using condoms consistently with a casual partner increased more than two-fold after the intervention among program students, following control for group, time and another 17 possible confounding variables (Table 3). Although an $82 \%$ increase in the OR for consistent condom use with a steady partner was also observed, the increase did not reach statistical significance at the level of $5 \%$. On the other hand, participation in program activities did lead to a $68 \%$ increase in modern contraceptive use by students at last intercourse. The variable sex was not found to be statistically significant in any of these three regression analyses. The dummy variable for adolescents' age, however, was significant only for modern contraceptive use, with older adolescents showing an increase in contraceptive use in relation to younger ones $(\mathrm{OR}=1.39$; 95\%CI: 1.01-1.91).

\section{Discussion}

The results of this study confirm that sex education programs can be effective in generating positive changes, such as an increase in condom and contraceptive use, in the sexual behavior of adolescents targeted by these programs. Although the present study follows the same logic as a true experimental design, it is considered a "quasi-experiment" 16 , since neither the participating municipalities nor the schools or in- dividuals participating in the intervention were randomly selected. This approach is generally used when there is a clear need for a specific intervention, when financial resources are limited and for ethical reasons, since the students participated voluntarily following authorization from their parents.

The evaluation design and the analysis carried out intended to correct for these sources of bias 16 . A relatively large number of control variables were evaluated and included in the multiple regression models to correct for their possible impact on the results. Differences in sex and age distribution, in particular, could have had a very large impact on the results if they had not been taken into account in the analysis. Despite these limitations, the results suggest that a sex education program with the characteristics of the one described in this paper is capable of promoting more responsible sexual behavior among adolescents.

Our results are in agreement with the conclusions of some of the most comprehensive reviews on the subject that analyzed the factors commonly associated with the success of this type of program. Some of the characteristics of the program described in this study coincide with those that have been found to be associated with the success of the program, such as duration of the intervention greater than 14 months, utilization of interactive activities, encouragement of openness in communication about sex, effective training of school teachers and clear reinforcement of values supporting program aims $3,18,19,20$. However, the use of qualitative methods in association with the quantitative nature of the evaluation performed here would allow a greater understanding of the key elements promoting behavioral changes among adolescents or acting as barriers for such changes.

The fact that there were no changes in the proportion of students who declared themselves 
Odds ratio, confidence interval and p-value for group, time and interaction between group and time in multilevel multiple logistic regression models of sexual behavior *.

\begin{tabular}{|c|c|c|c|c|}
\hline Sexual behavior & $\mathrm{n}$ & OR & $95 \% \mathrm{Cl}$ & $\mathrm{p}$ \\
\hline Ever having engaged in sexual practices & 4,204 & & & \\
\hline Group & & 0.82 & $0.61-1.10$ & 0.186 \\
\hline Time & & 0.90 & $0.64-1.28$ & 0.567 \\
\hline Group $x$ time & & 1.09 & $0.68-1.75$ & 0.723 \\
\hline Consistent condom use with casual partner & 774 & & & \\
\hline Group & & 0.61 & $0.38-0.99$ & 0.046 \\
\hline Time & & 0.79 & $0.47-1.33$ & 0.379 \\
\hline Group $\times$ time & & 2.19 & $1.10-4.37$ & 0.026 \\
\hline Consistent condom use with steady partner & 655 & & & \\
\hline Group & & 0.87 & $0.56-1.34$ & 0.522 \\
\hline Time & & 0.86 & $0.59-1.24$ & 0.420 \\
\hline Group $\times$ time & & 1.82 & $0.96-3.46$ & 0.065 \\
\hline Use of modern contraceptive at last intercourse & 944 & & & \\
\hline Group & & 0.79 & $0.55-1.14$ & 0.208 \\
\hline Time & & 0.95 & $0.65-1.40$ & 0.791 \\
\hline Group $x$ time & & 1.68 & $1.04-2.72$ & 0.033 \\
\hline
\end{tabular}

* Models were controlled for the other 17 independent variables described in the data analysis section.

to be sexually active corroborates the results of previous findings that the participation in sex education programs does not increase sexual practices ${ }^{3}$. This finding may help reduce resistance to these programs by those who express any concern that sex education stimulates sexual activity, since no real evidence exists on which to base this belief. In this sense, it is relevant to recall that this program did not stimulate abstinence in particular, but responsible sexual behavior.

The results of the present study are in agreement with those of a program on AIDS prevention for young adults also carried out in Brazil 21. The evaluation of this other program showed a statistically significant improvement in the communication of female students with their partners about sex and AIDS and increased condom use with non-monogamous partners. However, another integrated school and health-clinic reproductive health initiative for adolescents, undertaken in Bahia, Brazil by the State Departments of Health and Education to combat pregnancy and HIV infection in adolescents, failed to show any improvement in contraceptive use or in attendance at public health clinics, apparently due to problems in the implementation of the study 22.

It is widely recognized that the main mechanism for the prevention of risky sexual behavior is education prior to sexual debut, but this recognition in academic circles has failed to translate into widespread policies, except in some of the most developed countries in the world. Brazil is an example of many other developing countries with limited resources and increasing rates of diseases related to unsafe sexual behavior 23,24 and unplanned pregnancies among adolescents $25,26,27,28$. Although the inclusion of sex education in school has become an official policy of the Federal Government, the implementation of such policies depends on the municipal and state governments and has lagged well behind expectations, as in practically every other developing country.

Part of the reasons for this lack of implementation is that policy makers remain unconvinced of the effectiveness of sexuality education, and are concerned with opposition groups, which claim that sex education may stimulate premature sexual debut and sexual promiscuity among adolescents. It appears that the effectiveness of these programs in promoting more responsible sexual behavior has to be demonstrated in different cultures to be really convincing to those responsible for political decisions and the allocation of funds. The results of this study should be useful in showing that investment in implementing sex education in schools has a very positive and cost-effective return. The positive changes and the absence of increased sexual activity may be very helpful in overcoming the resistance to 
widespread sex education throughout the school system.

One particularly positive trait of the experience described in this paper is the partnership that was established between a private foundation associated with a large industrial company and the public health and education systems. This study shows that this type of collaboration is possible and can be very effective in inducing positive social changes. This is a model that has already been used successfully in Brazil in recent years 10 .

\section{Resumo}

Este artigo descreve a avaliação de possíveis mudanças no comportamento sexual de adolescentes que participaram de um programa de educação sexual implementado em escolas públicas selecionadas em quatro municípios de Minas Gerais, Brasil. O programa está inserido no contexto dos direitos reprodutivos, discute os riscos de práticas sexuais inseguras e enfoca os aspectos positivos da sexualidade. Utilizou-se um desenho quase-experimental com pré e pós-teste e grupo controle não-equivalente. Foram incluídos 4.795 questionários na análise dos resultados. O programa conseguiu dobrar o uso consistente do preservativo com parceiro casual e aumentar em $68 \%$ o uso de métodos anticoncepcionais modernos na última relação sexual. A intervenção não teve efeito sobre a idade da primeira relação sexual ou na prática de atividades sexuais. Concluindo, o programa foi eficaz em gerar mudanças positivas no comportamento sexual de adolescentes sem antecipar ou estimular a prática sexual.

Comportamento Sexual; Educação Sexual; Adolescentes
Awareness has increased within the private sector in Brazil with respect to social responsibility, with many companies creating non-profit foundations and institutes willing to invest in the development and health of young people. Thus, private initiative may be the final push required to proceed from good intentions and general policies to implementation of effective sex education programs in the public school and health systems. It is hoped that the experience described here will contribute towards further stimulating this positive trend.

\section{Contributors}

All the authors participated in preparing the research protocol, in data analysis and wrote the article.

\section{Acknowledgments}

This study was performed as an initiative of and with funds provided by the State Departments of Education and Health of Minas Gerais, the Odebrecht Foundation, the Belgo Foundation, the Beneficent Association of the Employees of the Belgo-Mineira Metallurgy Company (ABEB). The authors are also grateful to Márcia Campos and Gustavo Angeles for their contribution at different stages of the study and for their comments on the manuscript. 


\section{References}

1. World Health Organization. Promoting and safeguarding the sexual and reproductive health of adolescents. Geneva: World Health Organization; 2006. (Policy Brief, 4. Implementing the Global Reproductive Health Strategy).

2. Ross J, Godeau E, Dias, S. Sexual health. In: Currie C, Roberts C, Morgan A, Smith R, Settertobulte W, Samdal O, et al., editors. Young people's health in context: Health Behaviour in School-aged Children (HBSC) study. International Report from the 2001/2002 Survey. Copenhagen: WHO Regional Office for Europe; 2004. p. 153-60. (Health Policy for Children and Adolescents, 4).

3. Kirby DB, Laris BA, Rolleri LA. Sex and HIV education programs: their impact on sexual behaviors of young people throughout the world. J Adolesc Health 2007; 40:206-17.

4. Figueiró NMD. A produção teórica no Brasil sobre educação sexual. Cad Pesqui 1996; (98):50-63.

5. Figueiró NMD. Revendo a história da educação sexual no Brasil: ponto de partida para construção de um novo rumo. Nuances 1998; 4:123-33.

6. Secretaria de Educação Fundamental, Ministério da Educação. Parâmetros curriculares nacionais. Temas transversais: orientação sexual. Brasília: Secretaria de Educação Fundamental, Ministério da Educação; 1998.

7. Paiva V, Pupo LR, Barboza R. O direito à prevenção e os desafios da redução da vulnerabilidade ao HIV no Brasil. Rev Saúde Pública 2006; 40 Suppl:109-19.

8. Hughes J, McCauley AP. Improving the fit: adolescents' needs and future programs for sexual and reproductive health in developing countries. Stud Fam Plann 1998; 29:233-45.

9. Díaz M, Mello MB, Sousa MH, Cabral F, Silva RC, Campos M, et al. Outcomes of three different models for sex education and citizenship programs concerning knowledge, attitudes, and behavior of Brazilian adolescents. Cad Saúde Pública 2005; 21:589-97.

10. Centro de Pesquisas em Saúde Reprodutiva de Campinas/Fundação Odebrecht. Projeto Educação Afetivo-Sexual: sucessos e desafios na educação sexual de adolescentes da rede pública estadual de ensino de Belo Horizonte - relatório da avaliação externa. Campinas: Centro de Pesquisas em Saúde Reprodutiva de Campinas/Salvador: Fundação Odebrecht; 1999.

11. Costa ACG. Protagonismo juvenil: adolescência, educação e participação democrática. Salvador: Fundação Odebrecht; 2000.

12. Andrade HHSM, Marques CM, Gouveia MC, Gregório YM. Atendimento ambulatorial de adolescentes: a experiência do PAIA/ABEB. J Pediatr (Rio J) 1996; 72:319-23.

13. Cronbach LJ. Coefficient alpha and the internal structure of tests. Psychometrika 1951; 16:297-334.

14. Mello MB, Fruet MSB, Diaz M, Silva RC, Paiva V. Avaliação preliminar de impactos de um programa de orientação sexual de longa duração. In: Anais do VII Congresso Brasileiro de Sexualidade Humana. Rio de Janeiro: Sociedade Brasileira de Estudos em Sexualidade Humana; 1999. p. 74.
15. Fleiss JL. Statistical methods for rates and proportions. 2nd Ed. New York: John Wiley and Sons; 1981.

16. Bertrand JT, Magnani RJ, Rutenberg N. Evaluating family planning programs: with adaptations for reproductive health. Chapel Hill: Carolina Population Center, University of North Carolina at Chapel Hill; 1996.

17. Hosmer DW, Lemeshow S. Applied logistic regression. New York: John Wiley and Sons; 1989.

18. Grunseit A, Kippax S. Impact of HIV and sexual health education on the sexual behaviour of young people: a review update. Geneva: United Nations Joint Programme on HIV/AIDS; 1997.

19. Kirby D. A review of educational programs to designed to reduce sexual risk-taking behaviors among school-aged youth in the United States. Santa Cruz: ETR Associates; 1995.

20. Kirby D. Emerging answers: research findings on programs to reduce teen pregnancy. Washington DC: National Campaign to Prevent Teen Pregnancy; 2001.

21. Antunes MC, Peres CA, Paiva V, Stall R, Hearst N. Diferenças na prevenção da AIDS entre homens e mulheres jovens de escolas públicas em São Paulo, SP. Rev Saúde Pública 2002; 36(4 Suppl):88-95.

22. Magnani RJ, Gaffikin L, Aquino EML, Seiber EE, Almeida MCC, Lipovsek V. Impact of an integrated adolescent reproductive health program in Brazil. Stud Fam Plann 2001; 32:230-43.

23. Taquette SR, Vilhena MM, Paula MC. Doenças sexualmente transmissíveis e gênero: um estudo transversal com adolescentes no Rio de Janeiro. Cad Saúde Pública 2004; 20:282-90.

24. Oliveira FA, Pfleger V, Lang K, Heukelbach J, Miralles I, Fraga F, et al. Sexually transmitted infections, bacterial vaginosis, and candidiasis in women of reproductive age in rural Northeast Brazil: a population-based study. Mem Inst Oswaldo Cruz 2007; 102:751-6.

25. Bem-Estar Familiar no Brasil. Adolescentes, jovens e a pesquisa nacional sobre demografia e saúde: um estudo sobre fecundidade, comportamento sexual e saúde reprodutiva. Rio de Janeiro: BemEstar Familiar no Brasil; 1999.

26. Almeida MC, Aquino EM, Barros AP. School trajectory and teenage pregnancy in three Brazilian state capitals. Cad Saúde Pública 2006; 22:1397-409.

27. Chalem E, Mitsuhiro SS, Ferri CP, Barros MCM, Guinsburg R, Laranjeira R. Gravidez na adolescência: perfil sócio-demográfico e comportamental de uma população da periferia de São Paulo, Brasil. Cad Saúde Pública 2007; 23:177-86.

28. Baraldi ACP, Daud ZP, Almeida AM, Gomes FA, Nakano AMS. Adolescent pregnancy: a comparative study between mothers who use public and private health systems. Rev Latinoam Enferm 2007; 15(Spe):799-805

Submitted on $07 /$ Aug/2007

Final version resubmitted on $01 / \mathrm{Jul} / 2008$

Approved on 25/Aug/2008 